ఠ

Open Access Full Text Article

ORIGINAL RESEARCH

\title{
16-Hydroxycleroda-3, I3-dien- I 5, I6-olide induces anoikis in human renal cell carcinoma cells: involvement of focal adhesion disassembly and signaling
}

This article was published in the following Dove Press journal:

OncoTargets and Therapy

\author{
Yu-Chi Chen' \\ Bu-Miin Huang ${ }^{2}$ \\ Wei-Chang Lee ${ }^{3}$ \\ Yung-Chia Chen ${ }^{3,4}$ \\ 'Department of Urology, E-Da \\ Hospital, Kaohsiung, Taiwan; \\ ${ }^{2}$ Department of Cell Biology and \\ Anatomy, College of Medicine, \\ National Cheng Kung University, \\ Tainan, Taiwan; ${ }^{3}$ Graduate Institute \\ of Medicine, College of Medicine. \\ Kaohsiung Medical University, \\ Kaohsiung, Taiwan; ${ }^{4}$ Department \\ of Anatomy, School of Medicine, \\ Kaohsiung Medical University, \\ Kaohsiung, Taiwan
}

\begin{abstract}
Background: Clerodane diterpene, 16-hydroxycleroda-3,13-dien-15,16-olide (CD) isolated from Polyalthia longifolia Benth. \& Hook. f. var. pendula was found to be a potential apoptotic inducer in human leukemia, lung cancer, and colon cancer cells. However, the molecular mechanism remains elusive in renal system. Thus, in the present study, the regulatory mechanisms of CD-induced apoptosis in clear cell renal cell carcinoma (ccRCC) cells were investigated.

Materials and methods: Cell proliferation was evaluated by colony formation assay and cell cycle analyses. Protein expressions of focal adhesion (FA) related complexes were examined by immunofluorescence staining and Western blot analyses. Cell migration and invasion capabilities of renal cell carcinoma (RCC) cells were determined by wound healing and Transwell assays.

Results: CD inhibited cell colony formations, induced cell arrest at G2/M phase, and increased subG1 cell population both in 786-O and A-498. During CD treatment, the "rounded-up" cells were observed. The immune-staining of phosphorylated focal adhesion kinase ( $\mathrm{pFAK}$ ), vinculin, and paxillin displayed disassembly of the FA. Moreover, disruption of actin stress fibers was noted after $\mathrm{CD}$ treatment. Consistent with the findings, the expressions of pSrc, pFAK, FAK, vinculin, vimentin, and paxillin were all downregulated by $\mathrm{CD}$. In addition, $\mathrm{CD}$ attenuated cell migration and invasion activities accompanied by the reductions of $\mathrm{pNF}-\kappa \mathrm{B}$, matrix metalloproteinase (MMP)-2, MMP-9 as well as vascular endothelial growth factor expressions.

Conclusion: CD induced cell cycle arrest, FA complex disassembly, and the inactivation of migratory-related signaling pathways to induce apoptosis in ccRCC cells.
\end{abstract}

Keywords: focal adhesion, signaling pathway, Polyalthia longifolia, clerodane diterpene, migration, invasion, renal cell carcinoma, RCC

\section{Introduction}

Polyalthia longifolia Benth. \& Hook. f. var. pendula (Annonaceae) is native to India and is widely distributed in the tropical and subtropical regions of Asia and Africa. ${ }^{1}$ $P$. longifolia has been cultivated as an ornamental plant in India because it is an evergreen, tall, and slender tree. $P$. longifolia has been used in indigenous societies for treating pyrexia, diabetes, hypertension, and other diseases. ${ }^{1}$ Recently, one of the primary clerodane diterpenoid compounds isolated from $P$. longifolia, 16-hydroxycleroda-3,13-dien-15,16-olide (CD), has been shown to exhibit multiple pharmacological activities, such as antileishmanial, anti-inflammatory, anti-adipogenic, and cytotoxic effects. ${ }^{2-5}$ Studies have shown that $\mathrm{CD}$ exhibits antitumor activities in patients with leukemia, glioma, renal cell carcinoma (RCC), and oral cancer. ${ }^{6-9}$ However, the role
Correspondence: Yung-Chia Chen Department of Anatomy, School of Medicine, Kaohsiung Medical University, \#100, Shih-Chuan Ist Road, Kaohsiung 80708, Taiwan

Tel +88673 I 2 II 01 ext 2144

Fax +88673 II 9849

Email yungchia@kmu.edu.tw 
of CD in RCC cell cycle progression, migration, and invasion remains unknown.

Ninety percent of cases of kidney cancers are RCC, with an estimated incidence of 65,340 new cases and 14,970 deaths in 2018 worldwide. ${ }^{10}$ Localized RCC ( $<4 \mathrm{~cm}$ in size) can be successfully removed by nephrectomy, whereas metastatic $\mathrm{RCC}$ is notoriously resistant to radiotherapy and conventional chemotherapy. ${ }^{11}$ Approximately $30 \%$ of patients have a metastatic or unresectable disease at the time of diagnosis, and most of them die within 12-16 months. ${ }^{12}$

Clear cell RCC (ccRCC) is the most common subtype of renal neoplasms, which also accounts for the majority of deaths due to kidney cancer. ${ }^{13}$ The genetic aberration of von Hippel-Lindau (VHL) disease occurs as an initiating event in most cases of ccRCC. ${ }^{14}$ The VHL protein ( $\mathrm{pVHL}$ ) controls oxygen availability and regulates hypoxia-inducible factor (HIF) degradation. ${ }^{15}$ pVHL loss causes the sustained accumulation of the transcription factors HIF- $1 \alpha$ and HIF-2 $\alpha$, leading to the induction of HIF-responsive gene transcription and, then, further downstream events through the activation of pathways such as the phosphatidylinositol 3-kinases (PI3K)-protein kinase B (Akt)-mammalian target of rapamycin (mTOR) and mitogen-activated protein kinase-extracellular signalregulated kinase (MEK-ERK). ${ }^{14}$

Historically, standardized therapy of RCC has been based on immunotherapy, typically through either a high-dose of interleukin-2 or interferon alpha. ${ }^{12}$ However, treatment-related toxicities have restricted their usage because of elevated levels of HIF- $\alpha$ and the subsequent overexpression of vascular endothelial growth factor (VEGF), which promotes tumor angiogenesis. ${ }^{16}$ Therefore, the way forward in treating RCC now has to develop the new targeted therapies. The present study aimed to elucidate the detailed mechanisms involved in CD-induced apoptosis by determining cell cycle distribution, migration, and invasion activities in ccRCC cells.

\section{Materials and methods Preparation of CD}

The crystals of CD were extracted and isolated from the leaves of $P$. longifolia var. pendula as previously described. ${ }^{9}$ CD was dissolved in DMSO, which was purchased from Sigma-Aldrich Co. (St Louis, MO, USA). ${ }^{17}$

\section{Cell culture}

Human ccRCC cell lines (786-O and A-498) were purchased from BioResource Collection and Research Center (Hsinchu,
Taiwan) and grown in a culture medium (RPMI-1640 for $786-\mathrm{O}$ cells and $\alpha$-MEM for A-498 cells) containing 100 units $/ \mathrm{mL}$ penicillin, $100 \mu \mathrm{g} / \mathrm{mL}$ streptomycin, and $10 \%$ FBS (Thermo Fisher Scientific, Waltham, MA, USA) in a humidified atmosphere with $5 \% \mathrm{CO}_{2}$ at $37^{\circ} \mathrm{C}$. The cells were plated at $3 \times 10^{5}$ cells/well in $35-\mathrm{mm}$ culture dishes for performing Western blotting and $4 \times 10^{5}$ cells/well for a wound healing assay.

\section{Clonogenic assay}

Cells (786-O and A-498) were plated at a density of $1 \times 10^{4}$ cells per $35-\mathrm{mm}$ dish and incubated for 14 days to allow colonies to develop. At the endpoints of the clonogenic assays, cells were fixed, stained with $0.5 \%$ crystal violet containing $6 \%$ glutaraldehyde, and photographed under inverted microscope (Leica, Wetzlar, Germany).

\section{Cell cycle analysis}

After 24 hours of serum starvation, 786-O and A-498 cells were exposed to $\mathrm{CD}$ at $10-40 \mu \mathrm{M}$ for 24 hours and then harvested by trypsinization, washed in PBS twice, and fixed in $70 \%$ ice-cold $\mathrm{EtOH}$ overnight at $-20^{\circ} \mathrm{C}$. Cells were then washed and incubated in a solution containing $1 \%$ Triton $\mathrm{X}-100,50 \mu \mathrm{g} / \mathrm{mL}$ propidium iodide (PI), and $100 \mu \mathrm{g} / \mathrm{mL}$ RNase $\mathrm{A}$ at $37^{\circ} \mathrm{C}$ for 30 minutes in the dark. The percentage of the cell population in the $\mathrm{G} 0 / \mathrm{G} 1, \mathrm{~S}$, and, G2/M phases was analyzed from DNA content histograms using flow cytometry (Epics ${ }^{\circledR}$ XL ${ }^{\mathrm{TM}}$; Beckman Coulter, Inc., Brea, CA, USA). Apoptotic nuclei were identified as a subploid DNA peak (subG1 phase).

\section{Wound healing assay}

Cells (786-O and A-498) were seeded at a density of $4 \times 10^{5}$ cells/dish and were grown in a monolayer. A wound was created by carefully scratching using a $200-\mu \mathrm{L}$ pipette tip, and debris was subsequently removed by washing with a medium. Briefly, cells were incubated with CD $(0,10,20$, 30 , and $40 \mu \mathrm{M})$, and the migration of cells into the wounded area was monitored at 8 (786-O) and 20 hours (A-498). The distance between the two wound edges was normalized with a standard ruler and analyzed by Adobe Photoshop software.

\section{Transwell migration and invasion assay}

Cells were resuspended at a density of $2 \times 10^{5}$ cells/well in a medium containing $0.1 \%$ FBS. One hundred microliters of 786-O or A-498 cells was applied on top of the Transwell 
membrane in the upper chamber, and $700 \mu \mathrm{L}$ of chemoattractant was added to the lower chamber. For the invasion assay, Matrigel (BD Biosciences, San Jose, CA, USA) at a concentration of $2 \mathrm{mg} / \mathrm{mL}$ was applied in Transwell, and the cells were added on cross-linking Matrigel. After 24 hours, the cells that had migrated were fixed in $10 \%$ formalin for 15 minutes and washed three times with PBS. After staining with $0.25 \%$ Coomassie Brilliant Blue solution (SigmaAldrich), the images of migrated cells were analyzed by Adobe Photoshop software, whereas invaded cells were counted under microscope (Nikon, Tokyo, Japan).

\section{Gel electrophoresis and Western blotting}

After CD $(10-40 \mu \mathrm{M})$ treatment, RCC cells in $35-\mathrm{mm}$ dishes were washed with PBS and collected in a lysis buffer $(0.15 \%$ Triton $\mathrm{X}-100,2 \mathrm{mM} \mathrm{MgCl}, 25 \mathrm{mM}$ HEPES, 60 mM PIPES, 1 mM EDTA, 1 mM phenylmethylsulfonyl fluoride, $1 \mathrm{mM}$ sodium fluoride, $1 \mathrm{mM}$ sodium orthovanadate, $1 \mathrm{mM} \beta$-glycerol phosphate, $2.5 \mathrm{mM}$ pyrophosphate with complete ${ }^{\mathrm{TM}}$ protease inhibitor cocktail [SigmaAldrich]) and were sonicated 20 times with 1-second pulses. Protein concentrations were measured using a protein assay dye (Bio-Rad Laboratories Inc., Hercules, CA, USA), and the samples were stored at $-80^{\circ} \mathrm{C}$ until further analysis.

Protein samples were loaded in lanes (50-160 $\mu \mathrm{g}$ per lane) of a 10\%-12.5\% sodium dodecyl sulphate polyacrylamide gel (TOOLS HR Gradient gel solution; TOOLS, Taipei, Taiwan) subjected to electrophoresis, and transferred onto nitrocellulose membranes. Membranes were blocked for 1 hour at room temperature with 5\% nonfat milk or 5\% BSA (for phosphorylated antibodies) in Tris-buffered saline (TBS; $150 \mathrm{mM} \mathrm{NaCl}, 50 \mathrm{mM}$ Tris base, and $\mathrm{pH} 7.4$ ) containing $0.1 \%$ Tween 20 and incubated overnight at $4{ }^{\circ} \mathrm{C}$ with the desired primary antibody (Table 1) diluted in TBS, $0.1 \%$ Tween 20 , and $5 \%$ nonfat milk or $5 \%$ BSA. The secondary antibody included horseradish peroxidase-conjugated and/or alkaline phosphatase-conjugated anti-rabbit or anti-mouse antibodies (1:12,000 dilution; GeneTex, Inc., Irvine, CA, USA), and the bound antibodies were then detected using WesternBright Chemiluminescent Reagent (Advansta, San Jose, CA, USA) or alkaline phosphatase staining system (Sigma-Aldrich).

\section{Immunofluorescence}

RCC cells were grown on coverslips and treated with $0.1 \%$ DMSO and CD $(40 \mu \mathrm{M})$ for 24 hours. Briefly, the cells were fixed with $10 \%$ formalin phosphate for 10 minutes, permeabi-
Table I Antibodies

\begin{tabular}{|l|l|l|}
\hline Antibody & Dilution & Brand \\
\hline $\begin{array}{l}\text { Anti-vimentin (2707), anti- } \\
\text { pSrc (Tyr4I8; ab I33460), } \\
\text { anti-pNF-KB (Ser536; } \\
\text { ab76302), anti-glycerol-3- } \\
\text { phosphate dehydrogenase } \\
\text { (GAPDH; ab9484), P2 I } \\
\text { (abI09520) }\end{array}$ & & $\begin{array}{l}\text { IF: I:50 } \\
\text { company, Burlingame, } \\
\text { CA, USA) }\end{array}$ \\
\hline $\begin{array}{l}\text { Anti-paxillin (6I005I), anti- } \\
\text { PFAK (Tyr397; 6II722), } \\
\text { anti-FAK (6I0087), p53 } \\
\text { (554293) }\end{array}$ & IF: I:50 & \\
\hline $\begin{array}{l}\text { Anti-cyclin-dependent } \\
\text { kinase (CDK) 2, anti-CDK4, } \\
\text { anti-cyclin BI, anti-cyclin } \\
\text { DI, anti-vascular endothelial } \\
\text { growth factor (VEGF, }\end{array}$ & & BD Biosciences (San \\
sc-I52) & & Jose, CA, USA) \\
\hline $\begin{array}{l}\text { Anti-cyclin EI } \\
\text { (GTXI03045) anti-MMP-2 } \\
\text { (GTXI04577), anti-MMP-9 } \\
\text { (GTXI00458) }\end{array}$ & I:500 & $\begin{array}{l}\text { Santa Cruz } \\
\text { Biotechnology, Inc. } \\
\text { (Dallas, TX, USA) }\end{array}$ \\
\hline $\begin{array}{l}\text { Anti-vinculin (700062) } \\
\text { I:000 }\end{array}$ & $\begin{array}{l}\text { GeneTex, Inc. (Irvine, } \\
\text { CA, USA) }\end{array}$ \\
\hline
\end{tabular}

Abbreviations: IF, immunofluorescence; MMP, matrix metalloproteinase; PFAK, phosphorylated focal adhesion kinase; WB, Western blotting.

lized, and blocked with $0.3 \%$ Triton X-100 and 5\% normal goat serum (NGS) in PBS for 30 minutes. Then, they were incubated with primary antibodies diluted with $5 \%$ NGS in PBS overnight at $4^{\circ} \mathrm{C}$. All washes were performed using PBS. Alexa 488-conjugated donkey anti-mouse or anti-rabbit antibodies were used as secondary antibodies. Images were taken at $400 \times$ magnification under a fluorescent microscope (Nikon).

\section{Statistical analysis}

All experiments were performed a minimum of three times, and values are represented as mean \pm SD. Statistical differences were determined by analysis of variance, followed by Dunnett's post hoc test (GraphPad Prism software version 5.0). The fluorescent intensity was analyzed by unpaired $t$-test. A $P$-value of $<0.05$ was considered statistically significant.

\section{Results \\ Effects of $C D$ on the inhibition of proliferation in cCRCC cells}

Previously, we have shown that CD inhibits proliferation and induces mitochondrial-dependent apoptosis in ccRCC cells. ${ }^{9}$ As shown in Figure 1, CD suppressed colony 


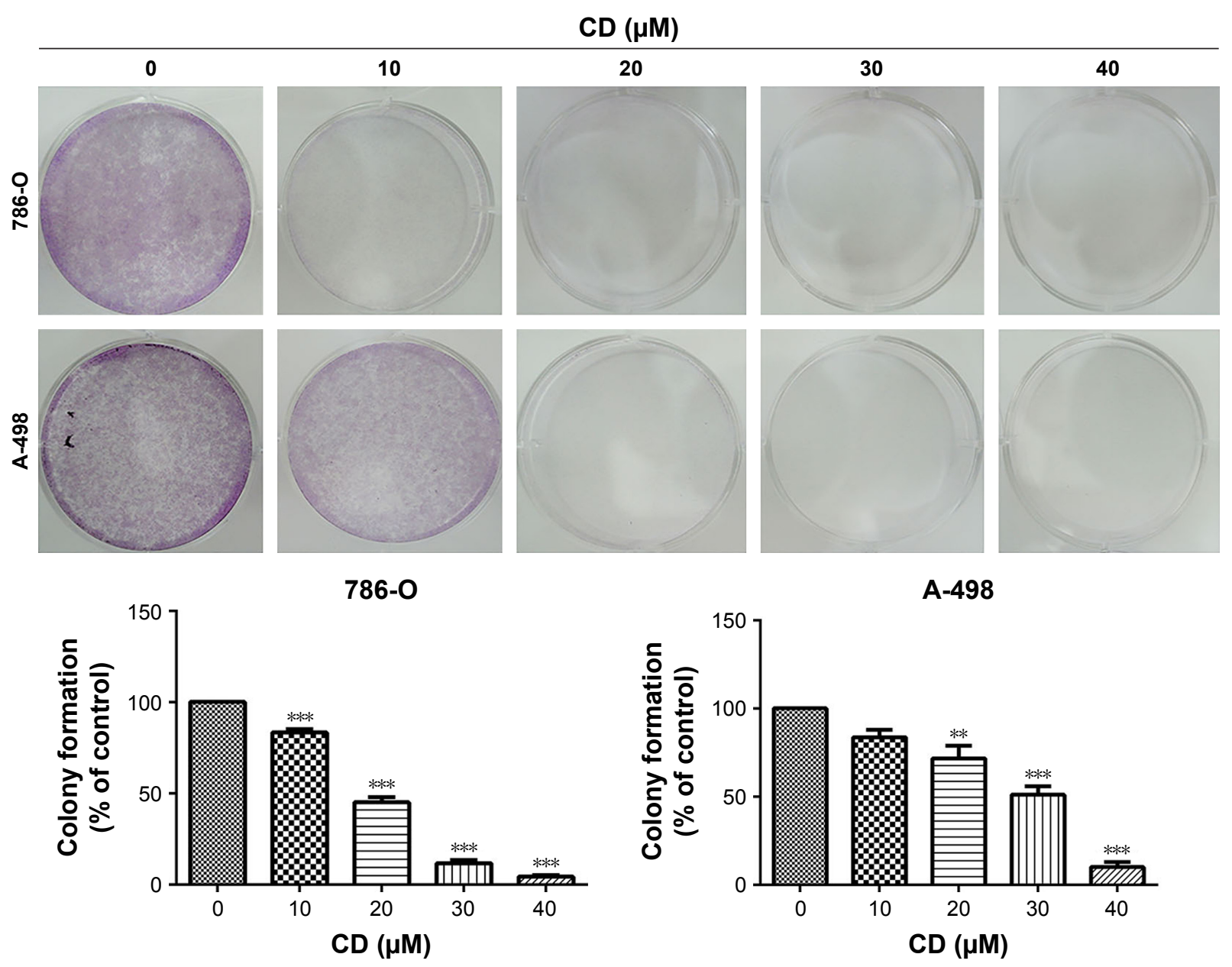

Figure I Clonogenic assays were performed to detect the reproductive capacity of 786-O and A-498 cells after CD treatment.

Notes: The figures shown are representative of one experiment; $* * P<0.0$ I, $* * * P<0.00$ I compared with the control ( $0 \mu \mathrm{M}$ group).

Abbreviation: CD, 16-hydroxycleroda-3,13-dien-15,16-olide.

formation in 786-O and A-498 cells, suggesting that CD inhibited cell proliferation. Cells were stained with PI and examined by flow cytometry to determine whether cell growth inhibited by $\mathrm{CD}$ is due to cell cycle arrest. Following treatment with $0,10,20,30$, and $40 \mu \mathrm{M} \mathrm{CD}$ for 24 hours, the percentages of $786-\mathrm{O}$ cells in the $\mathrm{G} 2 / \mathrm{M}$ phase were $10.6 \%, 10.3 \%, 13.7 \%, 15.4 \%$, and $24.5 \%$, respectively (Figure 2). Similarly, CD (10-40 $\mu \mathrm{M})$ significantly arrested A-498 cells at the $\mathrm{G} 2 / \mathrm{M}$ phase with an increasing population from $14 \%, 15.6 \%, 17 \%, 20.2 \%$ to $23.4 \%$. In both cell lines, the accumulation of subploid cells in the subG1 fraction (Figure 2) implies the effects of CD-triggered apoptosis in both ccRCC cells.

To further delineate the mechanism of CD-regulated cell cycle arrest, cell cycle regulatory proteins were evaluated by immunoblot analysis. Twenty-four-hour treatment with $\mathrm{CD}$ resulted in the downregulation of cyclin-dependent kinase 1 (CDK1), CDK2, CDK4, cyclin B1, cyclin D1, and cyclin E1 in a concentration-dependent manner (Figure 3A and $\mathrm{B})$. In addition, the CDK inhibitor p21 was eliminated by $\mathrm{CD}$ in both cell lines, and the tumor suppressor protein p53 was upregulated with the 24-hour treatment with CD (Figure 3A and B).

\section{Effects of $C D$ on migration and invasion in ccRCC cells}

A previous study has shown that $\mathrm{CD}$ at higher concentrations induced 786-O and A-498 cells to undergo rounding and detachment from the substratum, which suggests that CD exhibits anti-migration and anti-invasion activities. ${ }^{9} \mathrm{CD}$ significantly delayed the wound closure of 786-O and A-498 cells in a concentration-dependent manner (Figure 4A). In addition, the Transwell assay revealed that $\mathrm{CD}$ attenuated migration activity in 786-O at 10 and $40 \mu \mathrm{M}$ and in A-498 at 20 and $40 \mu \mathrm{M}$ (Figure 4B). Moreover, the anti-invasion activity was confirmed by performing a Matrigel-coated 

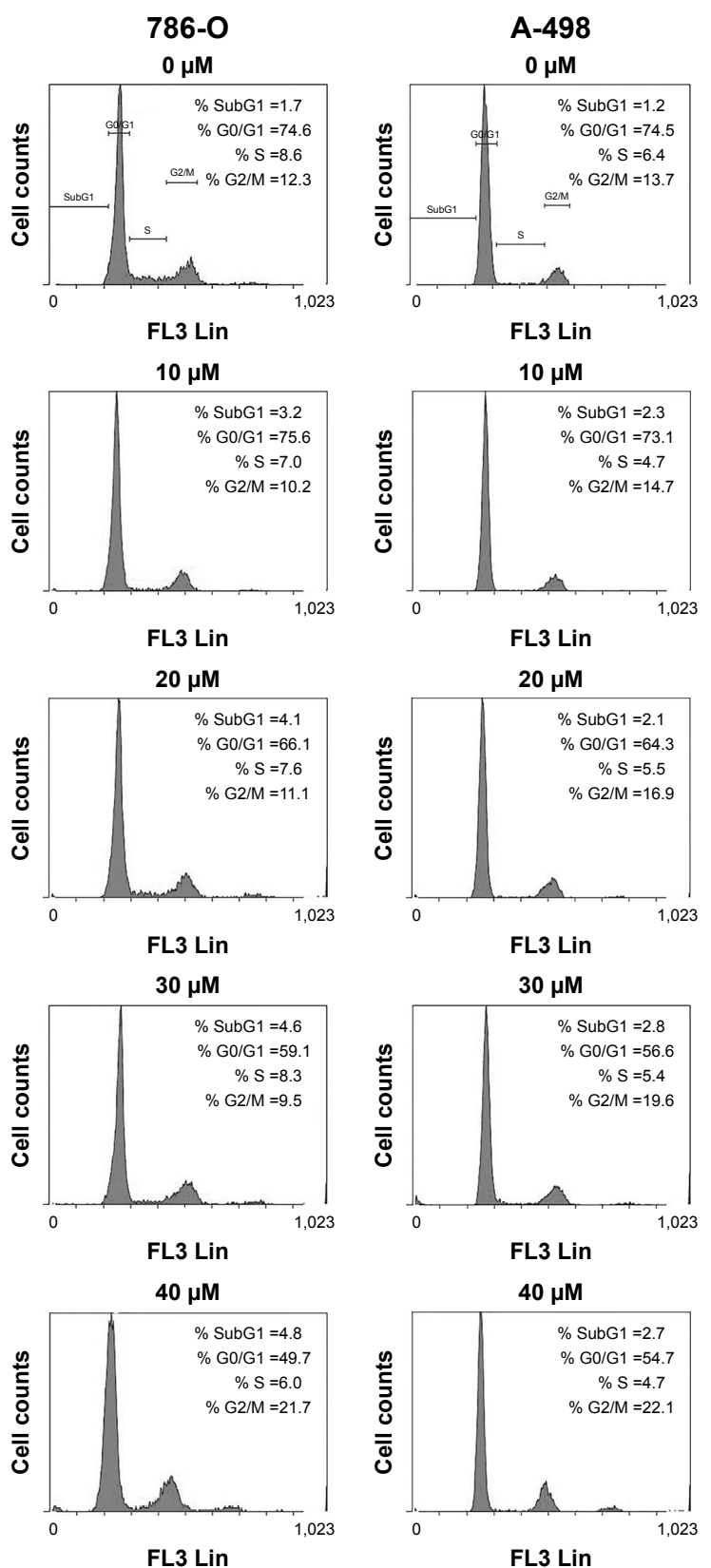

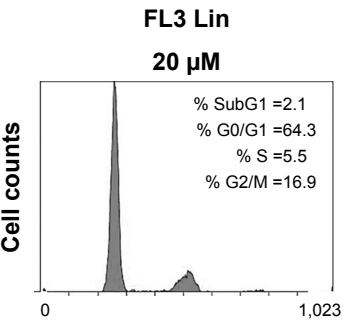

FL3 Lin
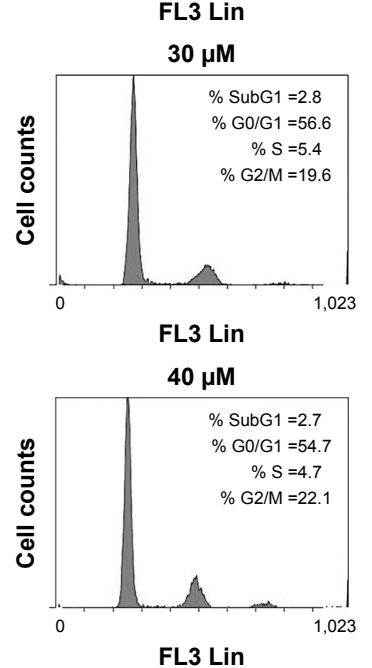
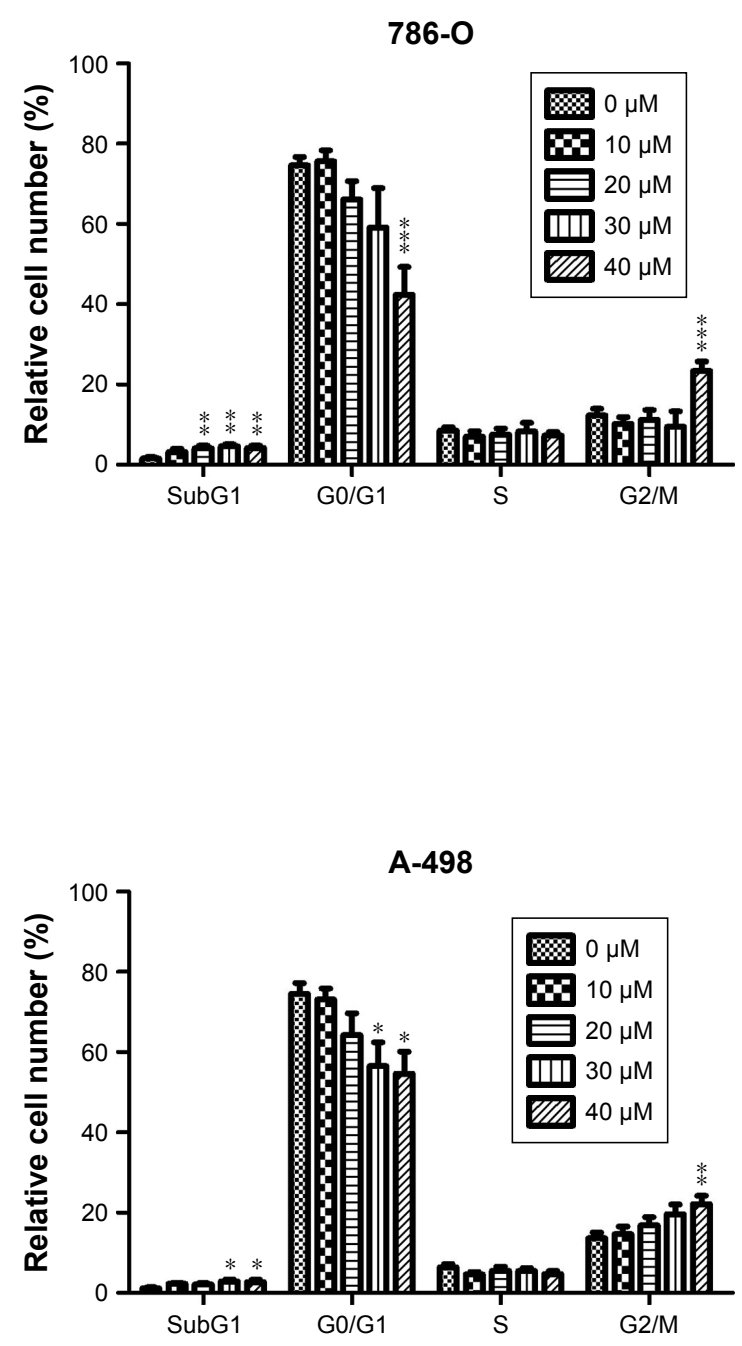

Figure 2 Cells (786-O and A-498) were treated with 0.1\% DMSO or CD (10-40 $\mu$ M) for 24 hours.

Notes: Cell cycle distribution was analyzed using flow cytometry. The cell population in the different phases of the cell cycle is demonstrated as a percentage. Representative images of flow cytometry analysis are displayed. Results are shown as mean \pm SD from 12 independent experiments. $* P<0.05$, $* * P<0.0$ I, $* * * P<0.001$ compared with the control ( $0 \mu \mathrm{M}$ group).

Abbreviations: CD, 16-hydroxycleroda-3,13-dien-15,16-olide; DMSO, dimethyl sulfoxide.

Boyden chamber assay. Figure 4C demonstrates that $\mathrm{CD}(40 \mu \mathrm{M})$ inhibited the invasion of $786-\mathrm{O}$ and A-498 cells.

\section{Effects of CD on focal adhesion (FA) complex proteins in ccRCC cells}

FAs are a type of adhesive contact between cells and the extracellular matrix. ${ }^{18}$ Focal adhesion kinase (FAK) is at the intersection of various signaling pathways that promote cancer growth and metastasis. ${ }^{19}$ FAK autophosphorylation at Tyr397 is critical for cancer progression and apoptosis prevention. ${ }^{19}$ We used immunofluorescence staining to confirm whether CD alters FA protein assembly. Three FA proteins, phosphorylated focal adhesion kinase (pFAK) (Tyr397), vinculin, and paxillin, were strongly expressed along the cell border with some staining seen under the 


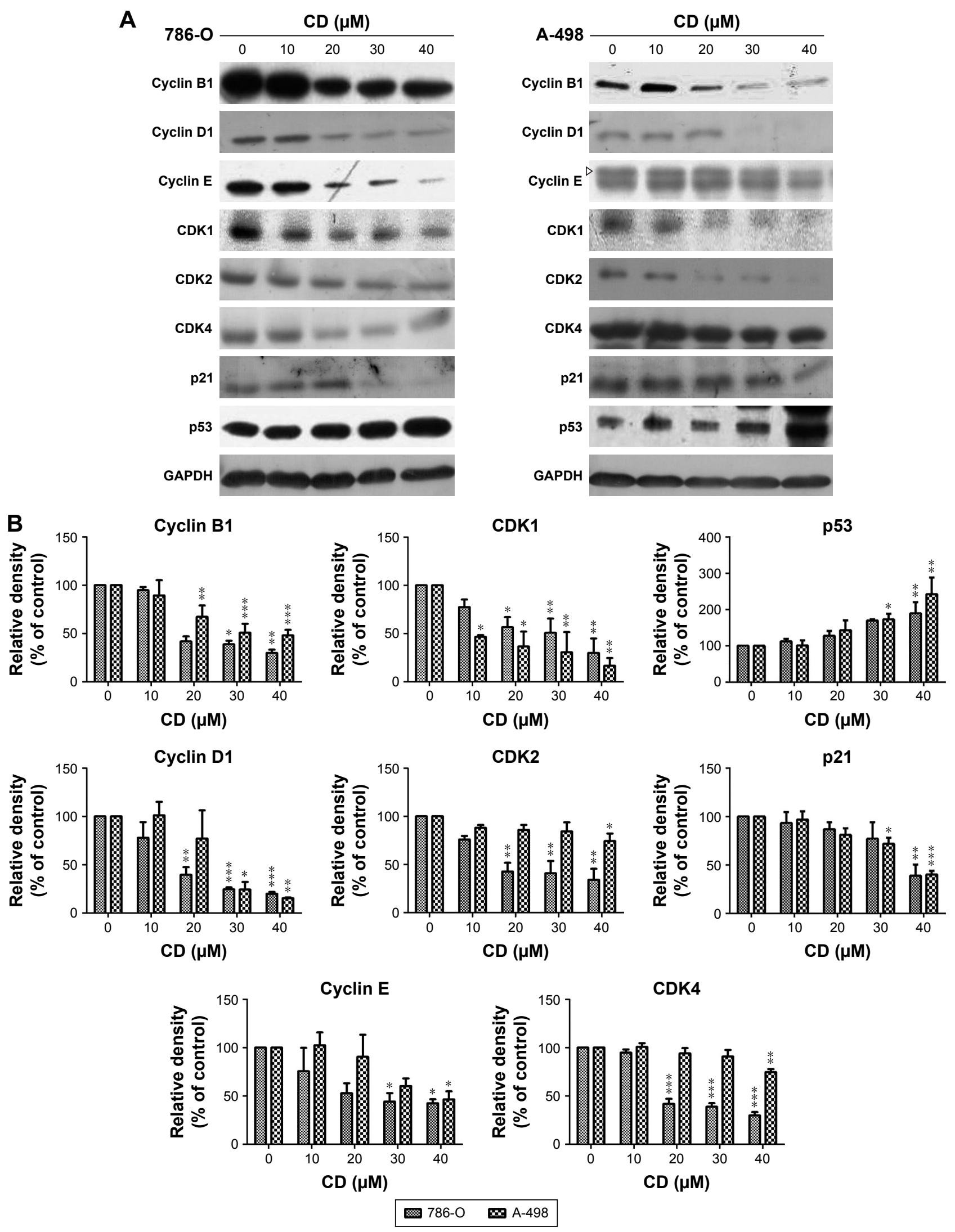

Figure 3 (A) Immunoblots of cyclins, CDKs, p2I, and p53 in CD-treated RCC cells. GAPDH was used as the internal control. (B) The bar graphs show densitometric data (mean \pm SD) from three to five independent experiments.

Notes: The figures shown are representative of one experiment; $* P<0.05, * * P<0.01$, $* * * P<0.00 \mathrm{I}$ compared with the control $(0 \mu \mathrm{M}$ group). Abbreviations: CD, 16-hydroxycleroda-3,13-dien-15,16-olide; CDK, cyclin-dependent kinase; RCC, renal cell carcinoma. 


\section{A}

A $\mathrm{CD}(\mu \mathrm{M})$
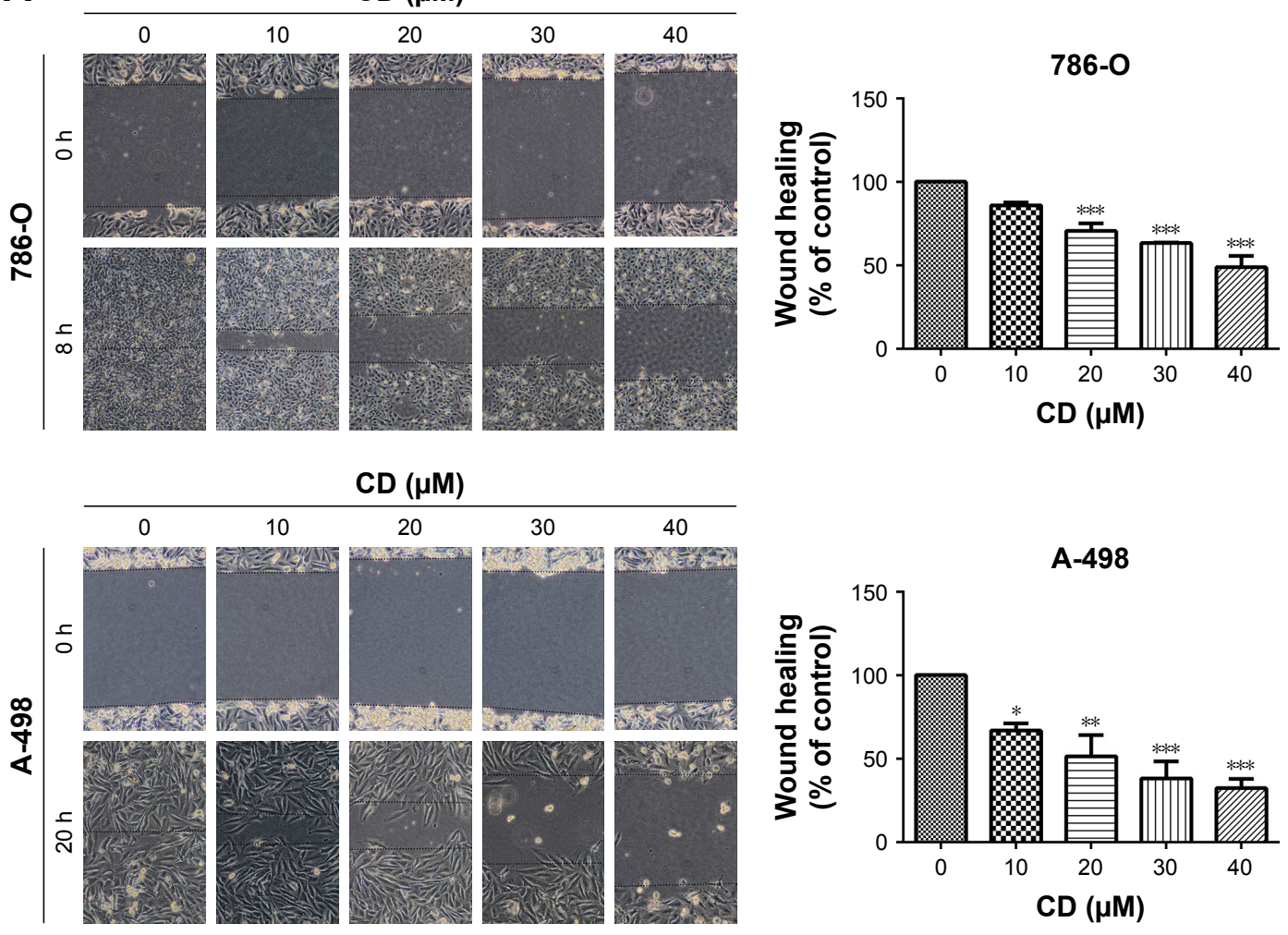

$\mathrm{CD}(\mu \mathrm{M})$
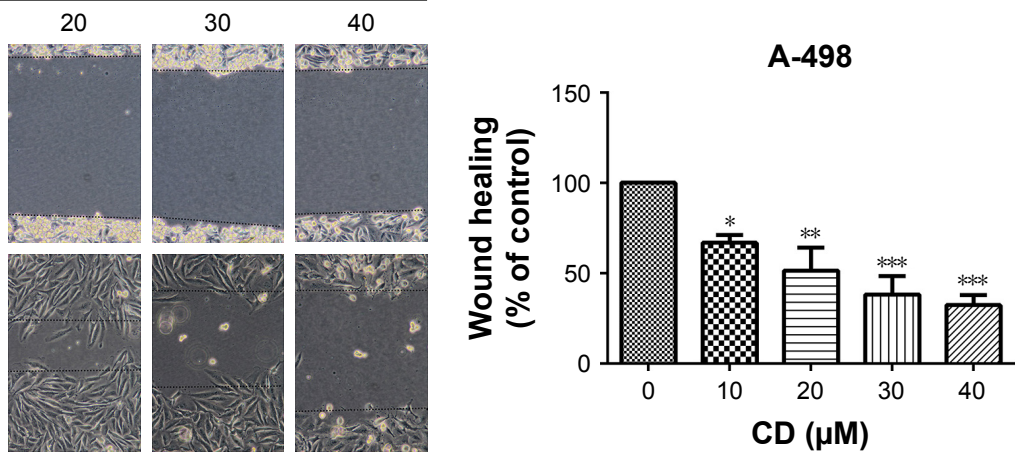

B
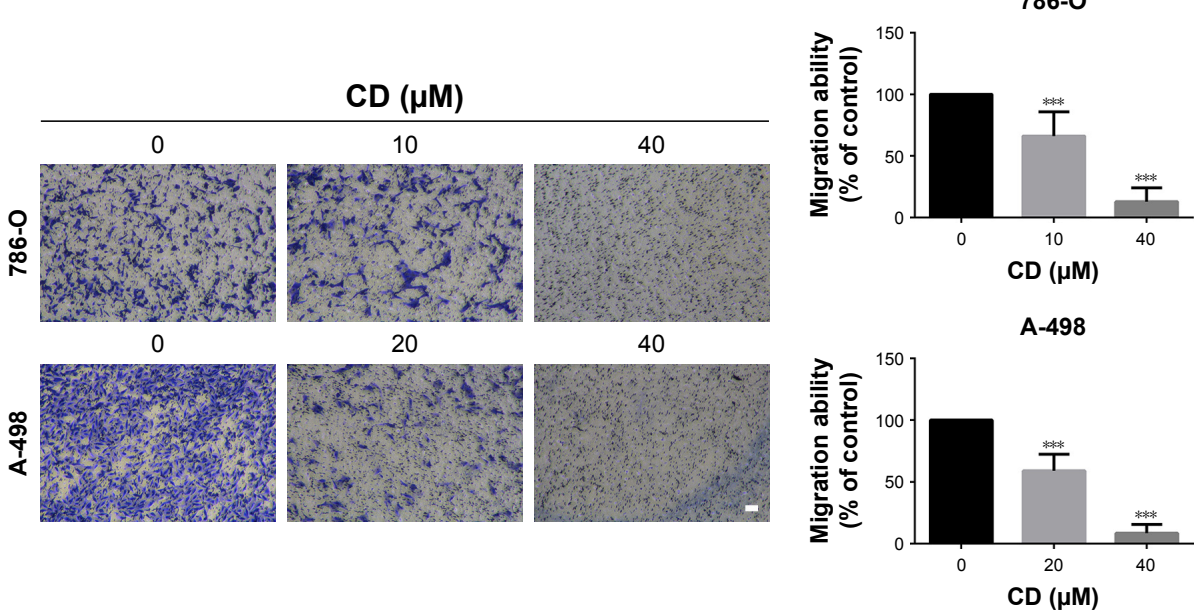

C
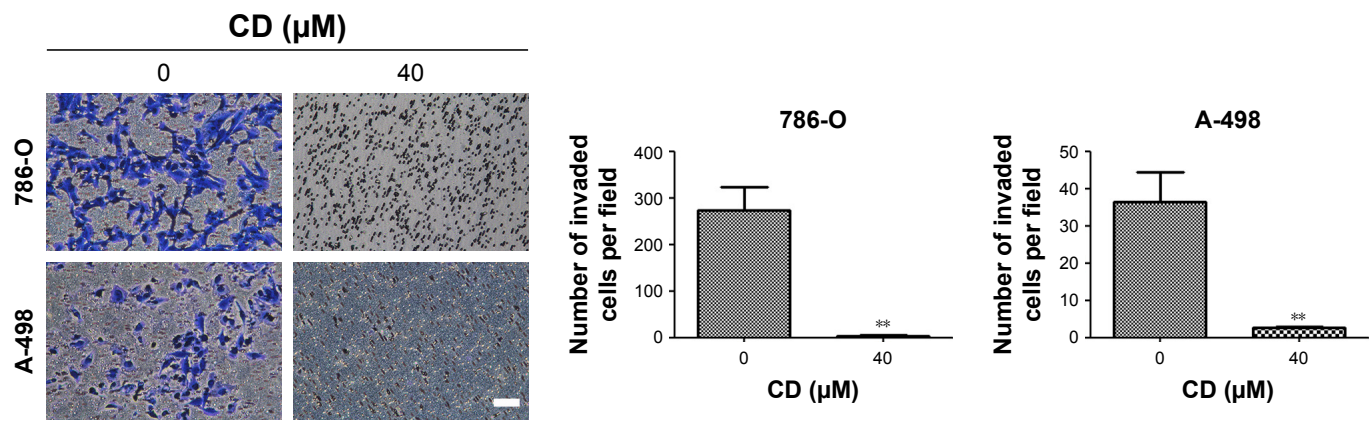

Figure 4 (A) Scratch assay of RCC cells treated with the indicated concentration of CD for 8 and 20 hours. (B) Transwell migration assay of RCC cells treated with $0.1 \%$ DMSO, 10 or $20 \mu \mathrm{M}$, and $40 \mu \mathrm{M}$ CD for 24 hours. Scale bar $=50 \mu \mathrm{m}$. 50x magnification. (C) Matrigel invasion assay of RCC cells treated with $0.1 \%$ DMSO or $40 \mu \mathrm{M}$ CD for 24 hours. Scale bar $=50 \mu \mathrm{m}$. 100 $\times$ magnification.

Notes: The bar graphs show the quantification of cell numbers that passed through the Transwell membrane from three independent experiments. $* P<0.05$, $* * P<0.0$, $* * * P<0.001$ compared with the control ( $0 \mu \mathrm{M}$ group).

Abbreviations: CD, 16-hydroxycleroda-3,I3-dien-15,16-olide; DMSO, dimethyl sulfoxide; RCC, renal cell carcinoma. 

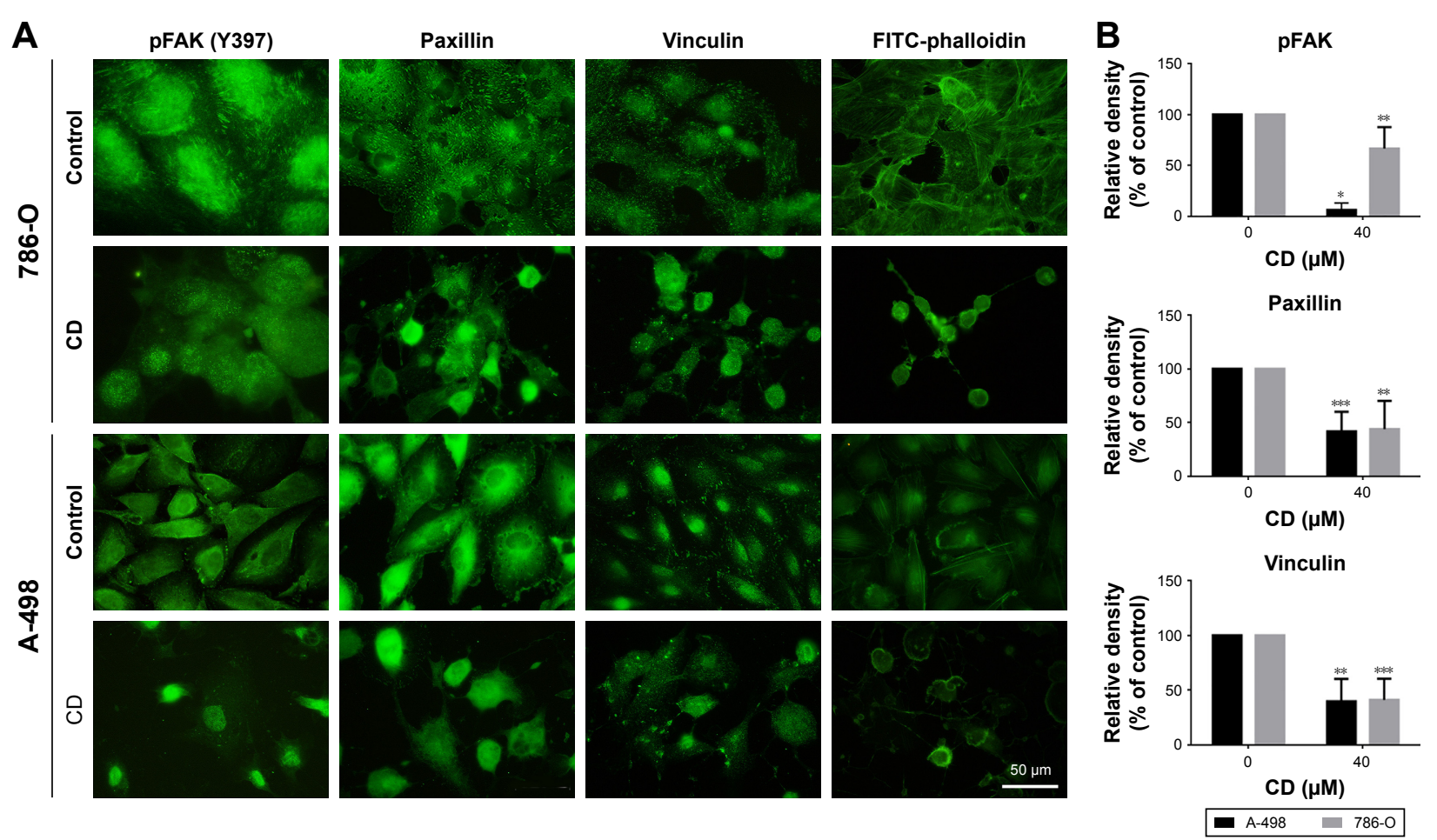

Figure 5 RCC cells were treated with $0.1 \%$ DMSO (control) or $40 \mu \mathrm{M}$ CD for 24 hours.

Notes: (A) Immunofluorescence staining was used to detect FA proteins. Stress fibers were determined by staining with FITC-phalloidin. (B) The bar graphs show densitometric data from four to eight different coverslips. Scale bar $=50 \mu \mathrm{m}$. $* P<0.05$, $* * P<0.01$, and $* * * P<0.001$.

Abbreviations: CD, I6-hydroxycleroda-3, I3-dien-15, I6-olide; DMSO, dimethyl sulfoxide; FA, focal adhesion; FITC, fluorescein isothiocyanate; pFAK, phosphorylated focal adhesion kinase; RCC, renal cell carcinoma.

cell body in vehicle-treated ccRCC cells (Figure 5A). These three FA proteins showed reduced staining after 24 hours of $\mathrm{CD}$ treatment (Figure 5B). Fluorescein isothiocyanate-phalloidin staining revealed morphological changes in CD-treated ccRCC cells that were not seen in vehicle-treated control cells (Figure 5A). Western blot analyses confirmed that the expression of pFAK (Tyr397), FAK, paxillin, and vinculin was decreased by 24 hours of CD treatment (Figure 6). Furthermore, other FAKassociated proteins, such as vimentin and pSrc (Tyr416), were downregulated by $\mathrm{CD}$ in a concentration-dependent manner (Figure 6).

\section{Effects of $C D$ on matrix metalloproteinase (MMP)-2, MMP-9, NF- $\kappa B$, and VEGF expressions}

FAK signaling plays a pivotal role in the production of MMP-2 and MMP-9 as well as the activation of NF- $\mathrm{KB}$, which subsequently activates tumor invasion. ${ }^{19} \mathrm{We}$ examined NF-кB, MMP-2, and MMP-9 protein expressions in CDtreated $786-\mathrm{O}$ and A-498 cells to determine the signaling molecules in cell migration and invasion inhibited by $\mathrm{CD}$ treated cells. The phosphorylation level of NF- $\mathrm{\kappa B}$ and expres- sions of MMP-2, MMP-9, and VEGF were suppressed after a 24-hour treatment with $\mathrm{CD}$, as demonstrated by Western blotting (Figure 7). CD significantly inhibited VEGF expression after 24 hours in 786-O and 48 hours of treatment in A-498 cells (Figure 7).

\section{Discussion}

Previously, we demonstrated that CD purified from $P$. longifolia leaves induces mitochondria-dependent apoptosis and inactivates oncogenic signaling pathways such as MEK-ERK, mTOR-HIF- $2 \alpha$, and Akt in ccRCC cells. ${ }^{9}$ However, the mechanisms of $\mathrm{CD}$-inhibited proliferation and induced apoptosis are not fully understood in ccRCC cells. The present study demonstrated that $\mathrm{CD}$ arrested the 786-O and A-498 cell cycles in the G2/M phase, with CDK1, CDK2, CDK4, cyclin B1, cyclin D1, cyclin E1, and p21 downregulation when 53 was simultaneously upregulated (Figure 3). Additionally, CD attenuated RCC migration and invasion through the inhibition of FAK signaling and HIF-downstream protein expression.

The tumor suppressor p53 induces the expression of numerous downstream targets including p21 and forkhead box class $\mathrm{O}$ family (FOXO) 3a, resulting in cell cycle arrest, 

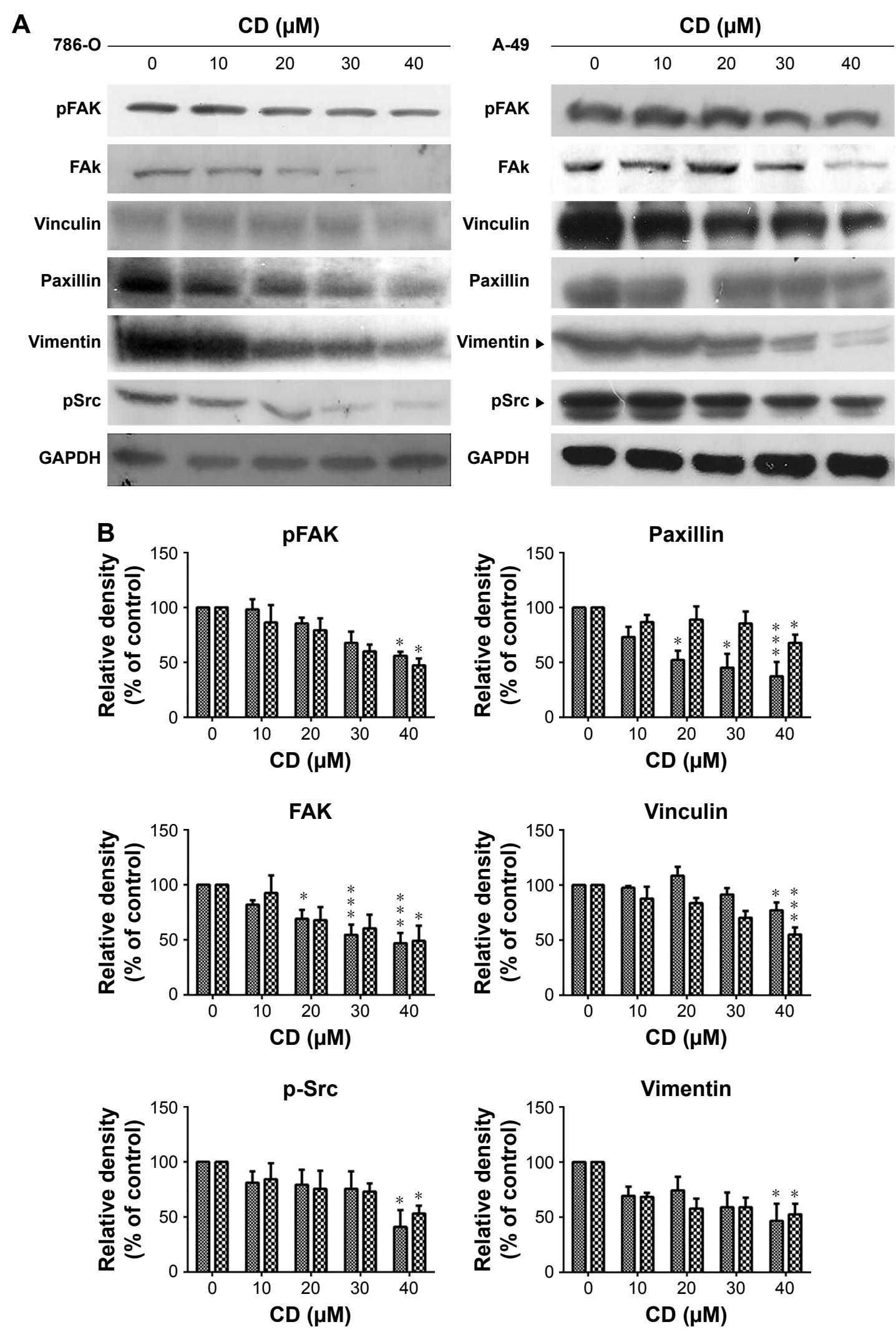

$786-0 \quad \mathrm{~A}-498$

Figure 6 (A) Immunoblots of FAK-related signaling molecules. The figures shown are representative of one experiment. (B) The bar graphs show densitometric data (mean \pm SD) from three independent experiments.

Note: ${ }^{*} P<0.05,{ }^{*} * *<0.001$ compared with the control ( $0 \mu \mathrm{M}$ group).

Abbreviations: CD, 16-hydroxycleroda-3, I3-dien-15, I6-olide; FAK, focal adhesion kinase; pFAK, phosphorylated focal adhesion kinase. 
A

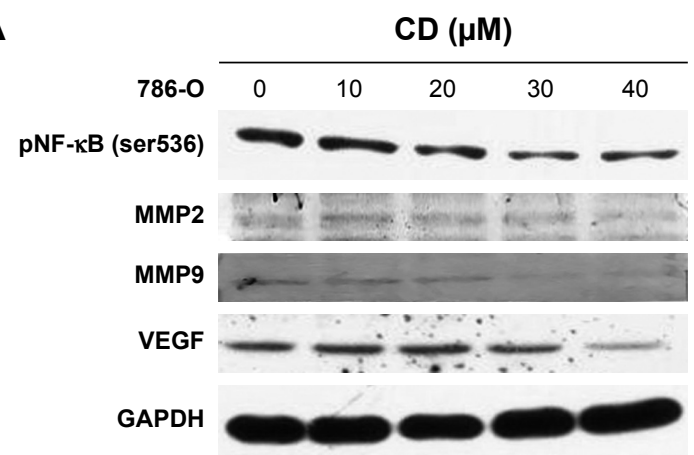

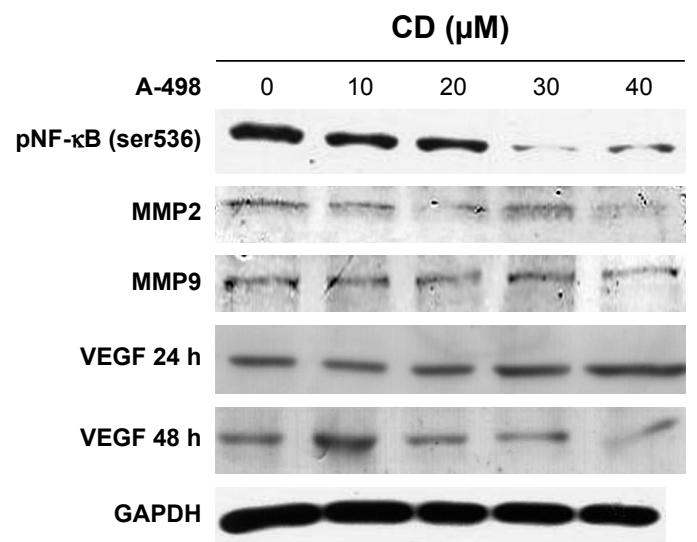

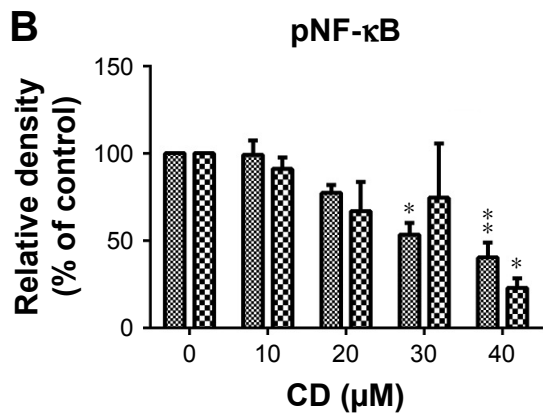

MMP2
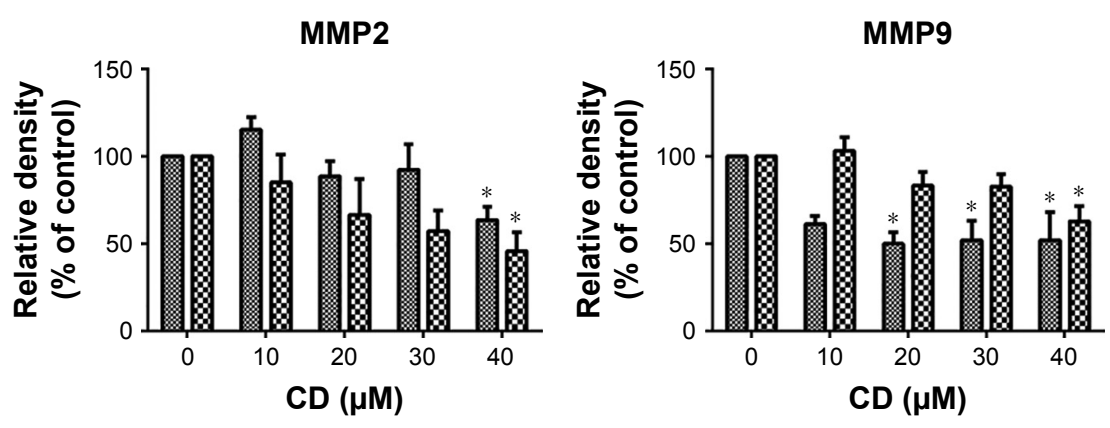
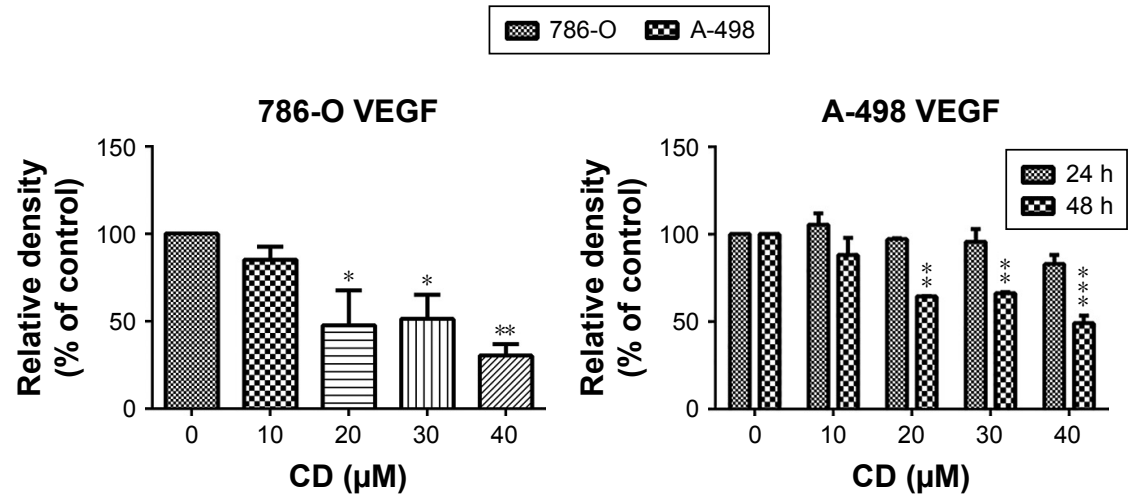

Figure 7 (A) Immunoblots of PNF-KB, MMPs, and VEGF in CD-treated RCC cells. The figures shown are representative of one experiment. (B) The bar graphs show densitometric data $(m e a n \pm S D)$ from three independent experiments.

Note: $* P<0.05, * * P<0.01, * * * P<0.001$ compared with the control $(0 \mu \mathrm{M}$ group).

Abbreviations: CD, 16-hydroxycleroda-3,13-dien-15,16-olide; MMP, matrix metalloproteinase; RCC, renal cell carcinoma; VEGF, vascular endothelial growth factor.

senescence, and apoptosis. ${ }^{20} \mathrm{p} 21$ was inhibited in CD-treated 786-O and A-498 cells in a concentration-dependent manner (Figure 3). Although the expression of p21 has been considered as an indicator of wild-type p53 activity, prevailing notions suggest that blockade of p21 levels in RCC cell lines sensitizes the cells to undergo apoptosis in response to DNA-damaging chemotherapy. ${ }^{21,22}$ Therefore, the inhibition of p21 might be beneficial and independent of p53 in CD-induced cell cycle arrest. On the other hand, it has been hypothesized that despite a normal p53 status, the function of p53 in RCC is dominantly repressed by an unknown mechanism. ${ }^{20}$ Nevertheless, p53 was rarely mutated in RCC. ${ }^{20,23}$ Accordingly, whether the other p53-specific inhibitor is involved in CD-induced G2/M phase arrest still needs more experimentation for clarification.

FAK drives various tumor-promoting signaling pathways, including survival, proliferation, invasion, and metastasis. ${ }^{19}$ Currently, many types of FAK inhibitors have been developed and undergone clinical trials. ${ }^{19}$ Through computational simulation, CD has been shown to interact with the autophosphorylation site of FAK, indicating that it is capable of treating tumor growth and/or metastasis. ${ }^{24}$ Our present results (Figures 4-7) are consistent with the observation that $\mathrm{CD}$ inhibits FA protein expression, cell migration, and invasion as well as MMP-2 and MMP-9 activities in glioblastoma cells. ${ }^{24}$ We determined that $\mathrm{CD}$ inhibits FA complexes 
(Figures 5 and 6), MMP expression (Figure 7), NF- $\mathrm{BB}$ activation (Figure 7), and VEGF expression (Figure 7) in RCC cells, suggesting its usage in the future development of anticancer drugs. The current study suggests that $\mathrm{CD}$ induces cell cycle arrest and ccRCC apoptosis partly through anoikis.

The pharmacologic inhibition of MEK leads to the compensatory upregulation of $\mathrm{PI} 3 \mathrm{~K} / \mathrm{Akt}$ signaling and promotes cancer cell survival. ${ }^{25} \mathrm{CD}$ induces ccRCC apoptosis through the inactivation of the Akt, mTOR, and MEK-ERK pathways. ${ }^{9}$ Thus, it is likely that FAK acts upstream of these molecules and serves as a critical regulator of CD-inhibited proliferation, migration, and invasion. Decreased staining in pFAK, paxillin, vinculin, and F-actin (Figures 5 and 6) may provide a rational explanation why there was an altered morphology in RCC cells after CD treatment.

$\mathrm{RCC}$ is a type of highly vascularized tumor and is characterized by the loss of the $V H L$ gene, therefore, presenting pseudohypoxia. ${ }^{15}$ As hypoxia is known to enhance migratory and invasive behaviour of tumor cells, HIF pathway induction triggers numerous transcriptional targets for tumor growth and metastasis. ${ }^{26}$ A strong correlation between HIF-2 $\alpha$ expression and increased pro-angiogenic factor levels has been shown in RCC cells. ${ }^{14}$ Therefore, an HIF inhibitor in anti-angiogenic cancer therapy represents a promising and innovative approach in cancer therapeutics. Furthermore, HIF-2 $\alpha$ inhibition influences p53 activation through reactive oxygen species (ROS) accumulation and DNA damage in RCC cells. ${ }^{27}$ Our previous study has shown that the expression of cMyc and HIF-2 $\alpha$ was attenuated whereas that of ROS and Foxo3a was increased after CD treatment. ${ }^{9}$

\section{Conclusion}

In summary, our results reveal that $\mathrm{CD}$ has antitumor, antimigratory, and anti-invasive activities in 786-O and A-498 cells. Recently, combination therapies have been attempted with agents targeting different pathways that are known to be critical in the pathophysiology of RCC. We suggest that CD is a useful and innovative agent for RCC treatment.

\section{Acknowledgments}

This work was supported by a grant from the Kaohsiung Medical University (PT-106001, M107015) and E-Da hospital (EDAHP107009). The authors would like to thank Enago (www.enago.tw) for the English language review.

\section{Author contributions}

Yu-Chi Chen and Yung-Chia Chen designed the study; participated in data analysis, interpretation, and write-up; drafted the manuscript; and critically revised the manuscript.
Wei-Chang Lee participated in the data collection and analysis. Bu-Miin Huang participated in data analysis, and interpretation and critically revised the manuscript. All authors contributed to data analysis, drafting and revising the article, gave final approval of the version to be published, and agree to be accountable for all aspects of the work.

\section{Disclosure}

The authors report no conflicts of interest in this work.

\section{References}

1. Katkar KV, Suthar AC, Chauhan VS. The chemistry, pharmacologic, and therapeutic applications of Polyalthia longifolia. Pharmacogn Rev. 2010;4(7):62-68.

2. Chang FR, Hwang TL, Yang YL, et al. Anti-inflammatory and cytotoxic diterpenes from formosan Polyalthia longifolia var. pendula. Planta Med. 2006;72(14):1344-1347.

3. Misra P, Sashidhara KV, Singh SP, et al. 16alpha-Hydroxycleroda-3,13 (14)Z-dien-15,16-olide from Polyalthia longifolia: a safe and orally active antileishmanial agent. Br J Pharmacol. 2010;159(5):1143-1150.

4. Zhao GX, Jung JH, Smith DL, Wood KV, Mclaughlin JL. Cytotoxic clerodane diterpenes from Polyalthia longifolia. Planta Med. 1991;57(4): 380-383.

5. Beg M, Shankar K, Varshney S, et al. A clerodane diterpene inhibit adipogenesis by cell cycle arrest and ameliorate obesity in C57BL/6 mice. Mol Cell Endocrinol. 2015;399:373-385.

6. Lin YH, Lee CC, Chan WL, Chang WH, Wu YC, Chang JG. 16-Hydroxycleroda-3,13-dien-15,16-olide deregulates PI3K and Aurora B activities that involve in cancer cell apoptosis. Toxicology. 2011;285(1-2):72-80.

7. Thiyagarajan V, Lin SX, Lee $\mathrm{CH}$, Weng CF. A focal adhesion kinase inhibitor 16-hydroxy-cleroda-3,13-dien-16,15-olide incorporated into enteric-coated nanoparticles for controlled anti-glioma drug delivery. Colloids Surf B Biointerfaces. 2016;141:120-131.

8. Cheng MF, Lin SR, Tseng FJ, et al. The autophagic inhibition oral squamous cell carcinoma cancer growth of 16-hydroxy-cleroda-3,14dine-15,16-olide. Oncotarget. 2017;8(45):78379-78396.

9. Liu C, Lee WC, Huang BM, Chia YC, Chen YC, Chen YC. 16-Hydroxycleroda-3, 13-dien-15, 16-olide inhibits the proliferation and induces mitochondrial-dependent apoptosis through Akt, mTOR, and MEK-ERK pathways in human renal carcinoma cells. Phytomedicine. 2017;36:95-107.

10. Siegel RL, Miller KD, Jemal A. Cancer statistics, 2018. CA Cancer J Clin. 2018;68(1):7-30.

11. Rini BI. New strategies in kidney cancer: therapeutic advances through understanding the molecular basis of response and resistance. Clin Cancer Res. 2010;16(5):1348-1354.

12. Koshkin VS, Rini BI. Emerging therapeutics in refractory renal cell carcinoma. Expert Opin Pharmacother. 2016;17(9):1225-1232.

13. Milella M, Felici A. Biology of metastatic renal cell carcinoma. J Cancer. 2011;2:369-373.

14. Clark PE. The role of VHL in clear-cell renal cell carcinoma and its relation to targeted therapy. Kidney Int. 2009;76(9):939-945.

15. Baldewijns MM, van Vlodrop IJ, Vermeulen PB, Soetekouw PM, van Engeland M, de Bruïne AP. VHL and HIF signalling in renal cell carcinogenesis. J Pathol. 2010;221(2):125-138.

16. Rapisarda A, Shoemaker RH, Melillo G. Antiangiogenic agents and HIF-1 inhibitors meet at the crossroads. Cell Cycle. 2009;8(24):4040-4043.

17. Chen CY, Chang FR, Shih YC, et al. Cytotoxic constituents of Polyalthia longifolia var. pendula. J Nat Prod. 2000;63(11):1475-1478.

18. Nagano M, Hoshino D, Koshikawa N, Akizawa T, Seiki M. Turnover of focal adhesions and cancer cell migration. Int J Cell Biol. 2012; Article ID 310616, 10 pages. 
19. Sulzmaier FJ, Jean C, Schlaepfer DD. FAK in cancer: mechanistic findings and clinical applications. Nat Rev Cancer. 2014;14(9):598-610.

20. Gurova KV, Hill JE, Razorenova OV, Chumakov PM, Gudkov AV. p53 pathway in renal cell carcinoma is repressed by a dominant mechanism. Cancer Res. 2004;64(6):1951-1958.

21. Weiss RH. p21Waf1/Cip1 as a therapeutic target in breast and other cancers. Cancer Cell. 2003;4(6):425-429.

22. Inoue H, Hwang SH, Wecksler AT, Hammock BD, Weiss RH. Sorafenib attenuates p21 in kidney cancer cells and augments cell death in combination with DNA-damaging chemotherapy. Cancer Biol Ther. 2011; 12(9):827-836.

23. Brodaczewska KK, Szczylik C, Fiedorowicz M, Porta C, Czarnecka AM. Choosing the right cell line for renal cell cancer research. Mol Cancer. 2016;15(1):83.
24. Thiyagarajan V, Lin SH, Chia YC, Weng CF. A novel inhibitor, 16-hydroxy-cleroda-3,13-dien-16,15-olide, blocks the autophosphorylation site of focal adhesion kinase (Y397) by molecular docking. Biochim Biophys Acta. 2013;1830(8):4091-4101.

25. Chappell WH, Steelman LS, Long JM, et al. Ras/Raf/MEK/ERK and $\mathrm{PI} 3 \mathrm{~K} / \mathrm{PTEN} / \mathrm{Akt} / \mathrm{mTOR}$ inhibitors: rationale and importance to inhibiting these pathways in human health. Oncotarget. 2011;2(3):135-164.

26. Krock BL, Skuli N, Simon MC. Hypoxia-induced angiogenesis: good and evil. Genes Cancer. 2011;2(12):1117-1133.

27. Bertout JA, Majmundar AJ, Gordan JD, et al. HIF2alpha inhibition promotes 553 pathway activity, tumor cell death, and radiation responses. Proc Natl Acad Sci U S A. 2009;106(34):14391-14396.

\section{Publish your work in this journal}

OncoTargets and Therapy is an international, peer-reviewed, open access journal focusing on the pathological basis of all cancers, potential targets for therapy and treatment protocols employed to improve the management of cancer patients. The journal also focuses on the impact of management programs and new therapeutic agents and protocols on

\section{Dovepress}

patient perspectives such as quality of life, adherence and satisfaction. The manuscript management system is completely online and includes a very quick and fair peer-review system, which is all easy to use. Visit http://www.dovepress.com/testimonials.php to read real quotes from published authors. 